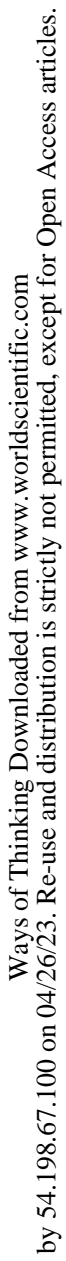

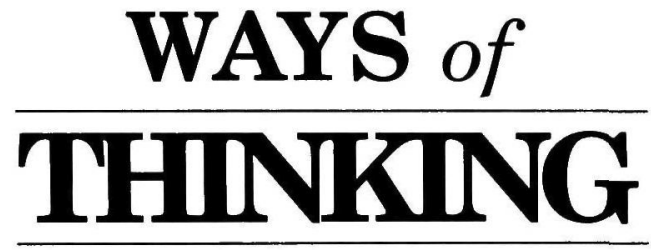


This page is intentionally left blank 


\section{WAYS of}

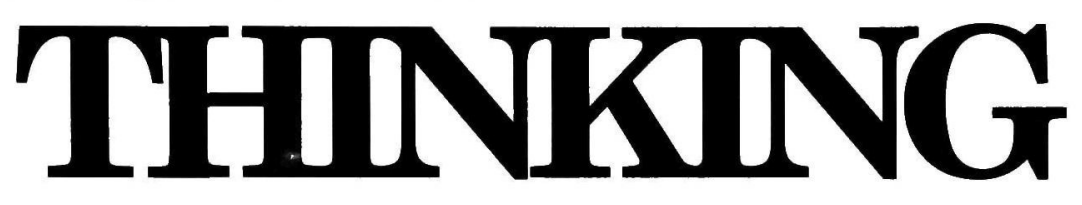

\section{The Limits of \\ Rational Thought \\ and \\ Artificial Intelligence}

\section{LÁSZLÓ MÉRŐ}

Department of

Experimental Psychology

Loránd Eötvös University

Budapest, Hungary

English translation by Anna C. Gösi-Greguss

English version edited by Viktor Mészáros

\section{World Scientific}


Published by

World Scientific Publishing Co. Pte. Ltd.

P O Box 128, Farrer Road, Singapore 9128

USA office: 687 Hartwell Street, Teaneck, NJ 07666

UK office: 73 Lynton Mead, Totteridge, London N20 8DH

\section{Library of Congress Cataloging-in-Publication Data}

Mérô, László.

Ways of thinking: the limits of rational thought and artificial intelligence/ László Merő; English translation by Anna C. Gösi-Greguss; English version edited by Viktor Mészáros.

p. $\mathrm{cm}$.

Includes bibliographical references and index.

ISBN 9810202660 . - ISBN 9810202679 (pbk.)

1. Thought and thinking. 2. Artificial intelligence.

I. Mészáros, Viktor. II. Title.

B105.T54M47 1990

$153.4 ’ 2-\mathrm{dc} 20$

$90-36036$

CIP

Original Hungarian text @) László Merő

English version ๔ 1990 by World Scientific Publishing Co. Pte. Ltd.

All rights reserved. This book, or parts thereof, may not be reproduced in any form or by any means, electronic or mechanical, including photocopying, recording or any information storage and retrieval system now known or to be invented, without written permission from the Publisher.

Typeset by TYPOTEX Ltd., Budapest

Printed in Singapore by JBW Printers \& Binders Pte. Ltd. 


\section{Acknowledgments}

For their contribution I would like to thank everybody who helped me in writing this book with his or her professional, personal, technical or stylistic pieces of advice, remarks, sensible incomprehension or patience in tolerating the tension going together with writing. My first thanks are due to my wife, Éva Kovácsházy and my colleagues at the Department of Experimental Psychology of Eötvös Loránd University of Budapest: Sándor Illyés, Éva Bányai, István Czigler, Zoltán Vassy, Csilla Greguss, Péter Vágó, Róbert Horváth, Katalin Varga, Andrea Dúll, Irén Murányi, and Judit Bokor. My thanks are also due to Tibor Vámos, Ferenc Bródy, György Csaba. Éva Gartner, János Herczeg, János Pataki, Erika Kovács, István Fekete, Csaba Pléh, Ilona Barkóczi, János Geier, András Vargha, Anikó Kónya, András Joó, Csaba Andor, István Síklaki, Zsuzsa Votisky, László Vekerdi, and the students attending my university courses for their valuable comments and reflections. Special thanks must go to Ágnes Fraller for the hundreds of objective, factual, stylistic and sometimes vitriolic remarks, Anna C. Gösi-Greguss for her more than professional translation and Viktor Mészáros for his help in editing the English version. 
This page is intentionally left blank 


\section{Contents}

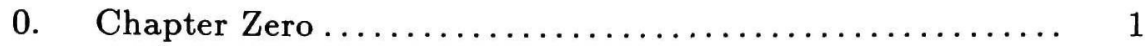

I. The diversity of thinking $\ldots \ldots \ldots \ldots \ldots \ldots \ldots, \quad 9$

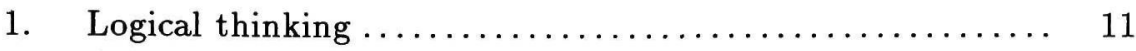

2. Common sense ............................... 26

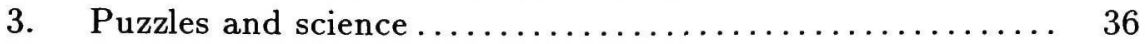

4. Ways of thinking in different cultures................. 45

5. Levels of thinking $\ldots \ldots \ldots \ldots \ldots \ldots \ldots \ldots \ldots \ldots \ldots \ldots \ldots \ldots \ldots, 62$

II. The building blocks of thinking $\ldots \ldots \ldots \ldots \ldots \ldots, 81$

6. Cognitive schemata........................... 83

7. The magic number seven ....................... 89

8. Some tens of thousands of schemata................ 97

9. Some tens of thousands of what? ................. 104

10. A challenge for programmers .................... 110

11. From beginners to grandmasters .................. 115

12. Profession - language - way of thinking............ 126

13. Artificial intelligence at candidate master level .......... 143

III. The strength of diversity $\ldots \ldots \ldots \ldots \ldots \ldots \ldots \ldots$

14. The limits of rationality ........................ 165

15. High-level cognitive schemata ................... 175

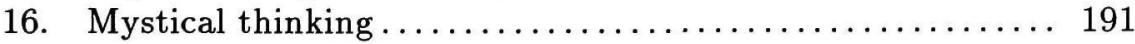

17. The trick of evolution......................... 200

18. Alternating the reference systems ................. 215

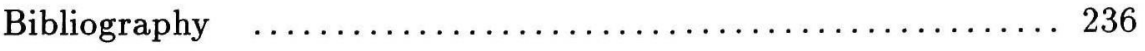

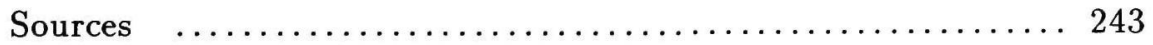

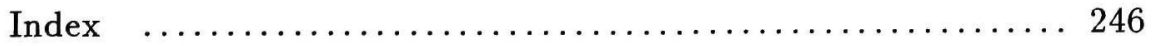

